\title{
Assessment of Hydrogen and LNG buses adoption as sustainable alternatives to diesel fuel buses in public transportation: Applications to Italian perspective.
}

\author{
Michele Vincenzo Migliarese Caputi ${ }^{* 1}$, Rossana Coccia ${ }^{2}$, Paolo Venturini ${ }^{3}$, Luca Cedola ${ }^{4}$, Domenico Borello ${ }^{5}$ \\ 1-2-3-4-5 Department of Mechanical and Aerospace Engineering -DIMA- Sapienza University of Rome Via Eudossiana, 18 - 00184 Roma, \\ ITALY
}

\begin{abstract}
This work deals with a technical and economical comparison between hydrogen and liquid natural gas (LNG) fueled buses with reference to the standard solution based on diesel fuel internal combustion engines. The level of service is evaluated considering the number of buses replaced and the average kilometers traveled each year for two levels. The economical comparison is made using the Total Cost of Ownership (TCO) method considering capital and operating costs. The costs of LNG and Diesel (at the pump in Italian market) are estimated with reference to the year 2020. Furthermore, an assessment of greenhouse gas emissions will be carried out starting from energy needs, adopting a "cradle to grave" approach, thus evaluating emissions from the well to the tank and from the tank to the wheel. The results show that the operating costs $(0.778 € / \mathrm{km})$ of LNG solution are lower than the Diesel ones $(1.072 € / \mathrm{km})$, while the hydrogen buses can become competitive in the next few .The production of hydrogen with water electrolysis considering the current electricity costs of the Italian market is expensive and involves a cost to the hydrogen pump 7,60 $€ / \mathrm{kg}$ which makes the operating cost of the hydrogen solution is equal to about $1.420 € / \mathrm{km}$ which makes this solution uncompetitive. It is also important to underline that the cost of green hydrogen production from water electrolysis strongly depends on the cost of electricity. The Life Cicle Analisis (LCA) analysis shows strong environmental benefits of the hydrogen solution in terms of $\mathrm{CO}_{2 \text { eq }}$ if the hydrogen is produced by electrolysis using renewable energy sources. In the other cases, the advantage of using hydrogen is not very strong as it is associated with the use of fossil fuels that release climatealtering substances.
\end{abstract}

\section{Introduction}

Issues related to Climate Changes boost the research of innovative solutions to radically reduce emissions. Paris Conference of the Parties (COP21) represents the start point for Europe transition to a decarbonized energy system [1]. It is expected that the implementation of COP21 objectives can have a strong impact, radically transforming the EU strategies in generating, distributing, storing and consuming energy. Major stakeholders are considering all available options to limit energy-related $\mathrm{CO}_{2}$ emissions to less than $770 \mathrm{Mt} / \mathrm{y}$ by 2050 , and it is a common opinion that hydrogen can constitute a very interesting solution [2]. According to ISPRA (Italian Higher Institute for Protection and Environmental Research, 2019), in Italy $23 \%$ of greenhouse gas emissions are attributable to road transport [3]. A report of European Environment Agency (EEA) states that air pollution caused over 400.000 deaths in Europe per year [5]. Italy is the first European country for premature deaths (more than 10.000) due carbon dioxide, while it is the second one (behind Germany) for deaths due to high nitrogen concentrations (about 3.000 deaths a year) and particulate matter ( $\left.\mathrm{PM}_{2.5}\right)$ (more than 52.000) [5]. Focusing on the Italian case it is possible to see that most of the pollution-related diseas are related to the low efficiency (and relatively large emissions) of public transportation, pushing travelers and commuters to use private cars instead of choosing public or shared mobility [5]. In this context, the energy transition can be achieved through a gradual shift from a system mostly based on fossil fuels to a more sustainable and renewable energy mix. The use of Liquefied Natural Gas (LNG) as a fuel could significantly contribute to the energy transition [6]. A very competitive solution consists in using green hydrogen as a fuel for electric buses equipped with batteries and hydrogen fuel cells, as also stated in the "Piano Nazionale Ripresa e Resilienza" representing the Italian implementation plan of the Next Generation EU action [7] Hydrogen and fuel cells technologies were identified amongst the new energy technologies needed to achieve a $60 \%$ to $80 \%$ reduction in GHGs emissions by 2050, in the European Strategic Energy Technology Plan presented along with the Energy Policy Package [8]. Use of hydrogen guarantees zero emissions [8][9] at the exhaust pipe and efficient power production in stationary, portable and transport applications. Hydrogen allows a wide diversification of energy sources as it can be produced from several raw materials. In combination with fuels cells, it can also improve energy efficiency in transport and contribute strongly to mitigate climate change especially when produced by renewable primary energy sources (green hydrogen).

\footnotetext{
* Corresponding author: michelevincenzo.migliaresecaputi@uniroma1.it
} 
Here we analyze the new emerging possibilities for reducing emissions of the transport sector through the substitution of diesel fuels with LNG or Hydrogen. Assuming a bus type and a level of service (in terms of $\mathrm{km} *$ bus/year) and computing the needs of the three considered fuels to satisfy such service, we present a comparison using the total cost of ownership (TCO) and Life Cycle Assessment (LCA) [10][36] methods, that allow to account for both the economic and environmental performance.

\section{From Diesel to Hydrogen getting through LNG}

Recent actions from the countries regulators, as mentioned before, are reducing the diffusion of Diesel fuel while increasing the viability of using alternative fuels, such as natural gas and hydrogen[11]. The effects on environmental quality, health and safety change using Diesel, LNG or hydrogen. Diesel is one of the responsible of urban areas environmental problems. In Italian cities, the urban public transport service mainly relies on the use of diesel buses. In Rome, for example, $92 \%$ of the surface service is characterized by the use of buses, most of which powered by Diesel engines [12]. To ensure a transition to a lower environmental impact, is necessary to consider the employment of LNG buses at first and later Hydrogen ones. For the supply, there are not critical problem because of the high capillary action of the Italian gas network [13] combined, with the possibility of building small NG liquefaction plants. Table 1 show the comparison of the calorific value between different fuels

Table 1. Comparison of the calorific value between different fuels

\begin{tabular}{|c|c|c|c|}
\hline $\begin{array}{c}\text { Type of } \\
\text { Fuel }\end{array}$ & $\begin{array}{c}\mathrm{LNG} \\
\left(\mathrm{T}=-160^{\circ} \mathrm{C},\right. \\
\mathrm{P}=1 \mathrm{~atm})\end{array}$ & $\begin{array}{c}\mathrm{H} 2 \\
\left(\mathrm{~T}=25^{\circ} \mathrm{C},\right. \\
\mathrm{P}=1 \mathrm{~atm})\end{array}$ & $\begin{array}{c}\text { Diesel } \\
\left(\mathrm{T}=25^{\circ} \mathrm{C},\right. \\
\mathrm{P}=1 \mathrm{~atm})\end{array}$ \\
\hline $\begin{array}{c}\text { Density } \\
{[\mathrm{g} / \mathrm{L}]}\end{array}$ & 446 & 0.0899 & 835 \\
\hline $\begin{array}{c}\mathrm{LHV} \\
{[\mathrm{kWh} / \mathrm{kg}]}\end{array}$ & 13.50 & 33.3 & 11.70 \\
\hline $\begin{array}{c}\mathrm{LHV} \\
{[\mathrm{Wh} / \mathrm{L}]}\end{array}$ & 6,100 & 3 & 10,000 \\
\hline
\end{tabular}

As reported in [14] the main advantages of using LNG compared to Diesel are lower maintenance costs, greater price stability, lower polluting emissions, greater safety. LNG has an energy content per unit mass greater than Diesel fuel, but it is smaller in terms of energy per unit

volume. Moreover, the low LNG storage temperature, needed to increases the energy contend, makes the tanks more complex than those for Diesel.

In this study the Hydrogen is considered to be employed with fuel cells, thus the only emission are water and hot air. Vehicles powered by Hydrogen fuel cells have a driving range similar to the Diesel fueled one, and they can be refueled in about the same time, which makes fuel cell vehicles suitable for long-haul. It is important to consider how the Hydrogen is produced and to assess the emissions associated to the Hydrogen (H2) transport. Nowadays, green Hydrogen is mainly produced by dissociation of water in electrolysers (using electricity from renewable sources). It can be used in the form of compressed gas or liquid cryogenic [15]. As compress gas Hydrogen can be supplied by existing natural gas pipelines. "To date, SNAM, the operator of the Italian gas network, estimates that over $70 \%$ of its pipelines are ready to transport hydrogen"'[16] .

\section{Methodology}

Is of a paramount important establishing a balance between the three main pillars of sustainable production, namely the social, economic, and environmental aspects[15]. TCO has long been recognized as an important technique for the evaluation of the total cost of ownership of a product from cradle to grave and it has frequently been used in decision making processes. The TCO approach considers not only the initial cost of purchase but also usage, maintenance and disposal/resale value of a product. According to this approach, in the long run a product with a higher purchase cost could still be economically more advantageous than others with lower purchase cost. In Addition, an indicator that allows to evaluate environmental performance of a product is the carbon footprint. It corresponds to the entire amount of greenhouse gas (GHG) produced to support the lifestyle and activities of a person directly and indirectly, or the production, use and disposal of a product. Carbon footprint is usually measured in tons of $\mathrm{CO}_{2 \mathrm{eq}}$, over the period of one year, and it can be associated with an individual, organization, product or event, among others. To evaluate this indicator the LCA approach can be used. LCA is the quantitative environmental assessment of a product over its entire life cycle, including raw material acquisition, production, transportation, use and disposal [15]. Therefore, it is a good way to measure the real environmental footprint of a product [10]. For a given transport system and with reference to the fuels used, LCA results in the so called "Well-to-Wheels" approach (WTW) [36]. For the sake of convenience, the evaluation in the present paper will be divided into two successive steps, "Well-to-Tank" (WTT) and "Tank-to-Wheels" (TTW), each considering specifics operations, as shown in (Fig. 1).

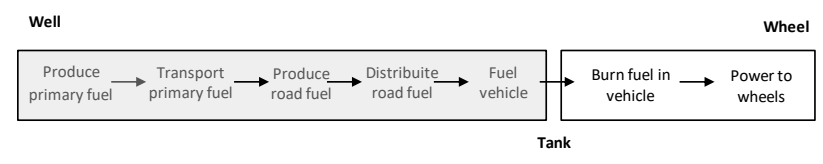

Fig. 1. "Well-to-Wheels" approach

TCO and LCA methods will be here applied to evaluate the three transport systems considered from both the economic and environmental points of view, to compare them aiming at giving an indication on the more convenient choice for the energy transition process.

\section{Vehicle specifications and operating data}

The present study is focus on local public transport in urban areas, are considered $12 \mathrm{~m}$ Buses, used in Italian 
medium/big cities. The comparison is performed considering three different kind of Bus.

1. Bus powered by Diesel fueled internal combustion engine (DF Bus)

2. Bus powered by LNG fueled internal combustion engine (LNG Bus)

3. Electric Bus in which electricity is produced by hydrogen fuel cells (FC Bus)

In the present study we assume that each Bus travels $90,000 \mathrm{~km} / \mathrm{y}$ (working for 300 days/y for 17 hours). To evaluate the scale effect, two fleets are considered: the first (A) is composed of 15 Buses, and the second one (B) by 30 Buses. This leads to the definition of the two global service levels reported in Table 2 .

Table 2. Global service level of the two considered Bus fleets.

\begin{tabular}{|c|c|c|c|}
\hline $\begin{array}{c}\text { Fleet } \\
\text { name }\end{array}$ & $\begin{array}{c}\text { No. } \\
\text { Bus }\end{array}$ & $\begin{array}{c}\mathrm{km} / \mathrm{y} \text { per } \\
\text { Bus }\end{array}$ & $\begin{array}{c}\text { Fleet service level } \\
\text { (km/year) }\end{array}$ \\
\hline A & 15 & 90,000 & $1,350,000$ \\
\hline B & 30 & 90,000 & $2,700,000$ \\
\hline
\end{tabular}

The main technical characteristics of the considered Buses are taken form the manufacturers web sites, and they will be presented in sections 4.1-4.3, where specific fuel consumption per 100 persons transported (SFC100) [17] will be also computed.

\subsection{DF Bus}

As a conventional Bus, we considered the Iveco Cursor 9, one of the newest in service in Rome. It has a range about $900 \mathrm{~km}$ and meets EURO VI emission limits. Table 3 reports the main characteristics of this Bus [18].

Table 3. Main characteristics of Cursor 9 Bus [18] .

\begin{tabular}{|c|c|}
\hline Model & Cursor 9 Diesel (Iveco) \\
\hline Size [m] & 12 \\
\hline Diesel storage [kg] & 371 \\
\hline $\begin{array}{c}\text { Estimated specific } \\
\text { consumption [kg/km] }\end{array}$ & $0.49[17]$ \\
\hline Emissions & Euro VI \\
\hline
\end{tabular}

Knowing the technical data sheet (provided by the manufacturer), it is possible to easily calculate the fuel required in the two scenarios analyzed (Table 2) as shown in tab. 4

Table 4. Annual consumption of diesel

\begin{tabular}{|c|c|}
\hline Service level & $\mathrm{kg}$ of Diesel/year \\
\hline A & 661,500 \\
\hline B & $1,323,000$ \\
\hline
\end{tabular}

\subsection{LNG Bus}

The LNG bus here considered is the Irizar Bus, one of the solutions recently adopted by some urban centers in Emilia-Romagna [19]. The storage pressure of $1 \mathrm{~atm}$ and temperature of $-160^{\circ} \mathrm{C}$ occupy a volume of tanks of approximately 1.260 liters. The specific consumption value will be used in the following for the calculation of the fuel requirement for the different service levels [17].
The environmental benefits offered by coaches with this technology reduce $\mathrm{CO}_{2}$ emissions by between 20 and $25 \%$, NOx by up to $60 \%$ and emissions of particulate matter by over $98 \%$. In addition to higher thermal performance than diesel, vibrations and noise emissions are also reduced by between $4-5 \mathrm{~dB}$ [20] [21]. The technical characteristics are shown in Table 5.

Table 5. Specifications of Irizar LNG Bus [21]

\begin{tabular}{|c|c|}
\hline Model & Irizar i4 \\
\hline Size [m] & 12 \\
\hline LNG storage [kg] & 240 \\
\hline $\begin{array}{c}\text { Estimated specific } \\
\text { consumption }[\mathrm{kg} / \mathrm{km}]\end{array}$ & $0.44[17]$ \\
\hline Emissions & Euro VI \\
\hline
\end{tabular}

The quantification of LNG needs for the two levels of service is shown in Table 6.

Table 6. Service level Bus fleet and quantity of fuel LNG

\begin{tabular}{|c|c|}
\hline Service level & $\mathrm{kg}$ of LNG / year \\
\hline A & 594,000 \\
\hline B & $1,1888,000$ \\
\hline
\end{tabular}

In relation to operating cost, it is estimated that its reduction can reach up to $35 \%$ of the total cost of consumption and maintenance, depending on the differential between the cost of gas and diesel. In the case under study, the specific consumption is assessed on the same database of the DF-bus [17]. The maintenance cost remains similar to that of a conventional diesel vehicle [20] [21][17].

\subsection{FC Bus}

The technical characteristics of the Bus, shown in Table 7, refer to the Solaris Urbino 12 Hydrogen equipped with the fuel cells supplied by Ballard. The hydrogen is stored in 5 cylinders of composite material of 312 liters at a pressure of 350 bar [22]. The actual hydrogen consumption of a FC Bus will depend on the operation of each specific Bus and will take into account passenger load, route, speed, and heating and cooling requirements. Recent Ballard publications, for the current generation of fuel cell electric buses, estimate an average fuel consumption of $8 \mathrm{~kg}$ kilograms of hydrogen per 100 kilometers [[23]] [[24]]. This value will be used in this study for the assessment of the hydrogen requirement for the two chosen service levels which is shown in the Table 8

Table 7. Specifications FC Bus [22]

\begin{tabular}{|c|c|}
\hline Model & Solaris Urbino 12 Hydrogen \\
\hline Size [m] & 12 \\
\hline $\begin{array}{c}\text { Battery power lithium-ion- } \\
\text { phosphate [kWh] }\end{array}$ & 28 \\
\hline $\begin{array}{c}\text { Fuel cell power FCmove } \\
{[\mathrm{kW}]}\end{array}$ & 70 \\
\hline Hydrogen storage $[\mathrm{kg}]$ & 36.8 \\
\hline Fuel cell lifetime [hours] & $>30,000[23]$ \\
\hline Emissions & Only heat and water \\
\hline
\end{tabular}


Table 8. Service level Bus fleet and quantity of fuel $\mathrm{H}_{2}$

\begin{tabular}{|c|c|}
\hline Service level & $\mathrm{kg}$ of Hydrogen / year \\
\hline A & 108,000 \\
\hline B & 216,000 \\
\hline
\end{tabular}

For the production of hydrogen, the case of production by SMR and electrolysis will be evaluated. For the latter case, production is based on electricity produced from renewable sources or extracted from the Italian national grid. The production costs related to hydrogen from electrolysis were estimated for two scenarios:

- electrolysers that use mains electricity,

- a direct physical connection between a renewable electricity source (RES) and the electrolysers.

In the first case, the emissions are linked to the type of network used; and in Europe and Italy electricity is not yet produced entirely from renewable sources. In the second case of direct connection, $100 \%$ of the electrolyser production is renewable.

\section{TCO analysis}

The methodology adopted to include economic factors in the assessment of sustainability is the Total Cost of Ownership (TCO) mentioned above. The TCO approach is implemented by considering the initial Capital Expenditure (Capex), maintenance and OPerating EXpense (Opex) incurred them in the buses lifetime (12 years) [22][23], (assuming no residual value for the assets); they are discounted at a $4 \%$ financial rate too. In fuel cell buses, after an estimated operating period of 30.000 hours ( 6 years see, section 4 ) should be considered a cost of overhauling (refurbished) (The cost of replacing the cells is estimated at $€ 24.000$ (\$ 30.000 USD) [22] with estimated downward costs in the coming years. A disposal cost equal to $1 \%$ of the purchase cost is assumed.

The Net Present Value (NPV), having expressed the Opex costs in terms of $€ / \mathrm{km}$, allows us to define the operating cost in the same way.

\subsection{DF Bus}

In Table 9 it is possible to evaluate the purchase, fuel and maintenance costs for the Bus mentioned in section 4.1.

Table 9. DF Bus Costs

\begin{tabular}{|c|c|}
\hline Model & Diesel Urban Bus \\
\hline Purchasing cost $[€]$ & $250,000[25]$ \\
\hline Fuel cost $[€ / \mathrm{kg}]$ & $1.576[26]$ \\
\hline Maintenance cost $[€ / \mathrm{km}]$ & $0.30[27]$ \\
\hline
\end{tabular}

In Table 10 are reported the Capex and disposal costs of the DF Bus fleet for the two scenarios.

Table 10. Capex of the DF Bus fleet

\begin{tabular}{|c|c|c|}
\hline Scenario & 1 & 2 \\
\hline Capex DF Bus [ $€$ ] & $3,750,000$ & $7,500,000$ \\
\hline $\begin{array}{c}\text { Disposal cost estimated at 1\% of } \\
\text { the Capex DF Bus }\end{array}$ & \multicolumn{2}{|c|}{$1 \%$} \\
\hline Disposal cost $[€]$ & 37,500 & 75,000 \\
\hline
\end{tabular}

In Table 11 are reported the Opex of the Diesel Bus fleet for the two scenarios:

Table 11. Opex of the DF Bus fleet

\begin{tabular}{|c|c|c|}
\hline Scenario & 1 & 2 \\
\hline Fuel Costs Annual $[€]$ & $1,042,556$ & $2,085,111$ \\
\hline Maintenance cost $[€]$ & 405,000 & 810,000 \\
\hline Total Opex DF Bus $[€]$ & $1,447,556$ & $2,895,111$ \\
\hline
\end{tabular}

Table 12 shows the NPV and the operating cost in $€ / \mathrm{km}$ and the \% Capex and \% Opex for the DF Bus fleet. The NPV defines the present value of the Capex and Opex expenses (12 year) by discounting them (at $4 \%$ financial rate) on the basis of the rate of return.

Table 12. NPV and operating cost DF Bus fleet

\begin{tabular}{|c|c|c|}
\hline Scenario & 1 & 2 \\
\hline NPV $[€]$ & $17,358,839$ & $34,717,679$ \\
\hline Operating cost $€ / \mathrm{km}$ & 1.072 & 1.072 \\
\hline$\%$ Capex & $72 \%$ & $72 \%$ \\
\hline$\%$ Opex & $28 \%$ & $28 \%$ \\
\hline
\end{tabular}

\subsection{LNG Bus}

In Table 13 are reported the purchasing, fuel and maintenance costs for the LNG Bus mentioned in section 4.2 .

Table 13. LNG Bus Costs

\begin{tabular}{|c|c|}
\hline Model & LNG Urban Bus \\
\hline Purchasing cost $[€]$ & $258,000[28]$ \\
\hline Fuel cost $[€ / \mathrm{kg}]$ & $0.950[26]$ \\
\hline Maintenance cost $[€ / \mathrm{km}]$ & $0.27[27]$ \\
\hline
\end{tabular}

In Table 14 are reported the Capex and disposal cost of the LNG Bus fleet for the two scenarios.

Table 14. Capex of the LNG Bus fleet

\begin{tabular}{|c|c|c|}
\hline Scenario & 1 & 2 \\
\hline Capex LNG Bus [€] & $3,870,000$ & $7,740,000$ \\
\hline $\begin{array}{c}\text { Disposal cost estimated at } \\
1 \% \text { of the Capex LNG Bus }\end{array}$ & \multicolumn{2}{|c|}{$1 \%$} \\
\hline Disposal cost $[€]$ & 38,700 & 77,400 \\
\hline
\end{tabular}

In Table 15 is reported the Opex of the LNG Bus fleet for the two scenarios.

Table 15. Opex of the LNG Bus

\begin{tabular}{|c|c|c|}
\hline Scenario & 1 & 2 \\
\hline Fuel Costs Annual $[€]$ & 564,300 & $1,128,600$ \\
\hline Maintenance cost [€] & 364,500 & 729,000 \\
\hline Total Opex LNG Bus [€] & 928,800 & 1.857 .600 \\
\hline
\end{tabular}

Table 16. shows the NPV and the operating cost in $€ / \mathrm{km}$ and the \% Capex and \% Opex for the LNG Bus fleet.

Table 16. NPV and operating cost of LNG Bus fleet

\begin{tabular}{|c|c|c|}
\hline Scenario & 1 & 2 \\
\hline NPV [ $€]$ & $12,611,028$ & $25,222,057$ \\
\hline Operating cost $€ / \mathrm{km}$ & 0,778 & 0,778 \\
\hline$\%$ Capex & $81 \%$ & $81 \%$ \\
\hline
\end{tabular}




$$
\% \text { Opex }
$$

$19 \%$

$19 \%$

\subsection{FC Bus}

In Table 17 it is possible to value the purchasing, fuel and maintenance costs for the FECBs mentioned in section 4.3 .

Table 17. FC Bus Costs

\begin{tabular}{|c|c|}
\hline Model & Hydrogen Urban Bus \\
\hline Purchasing cost $[€]$ & $625,000[30]$ \\
\hline Fuel cost $[€ / \mathrm{kg}]$ & See the (Table 18) \\
\hline $\begin{array}{c}\text { Maintenance cost }[€ / \mathrm{km}] \\
0.32[8][24]\end{array}$ \\
\hline $\begin{array}{c}\text { Maintenance cost of Fuel Cell } \\
{[€ / \mathrm{km}]}\end{array}$ & $0.1[8][24]$ \\
\hline \begin{tabular}{c} 
Cost replacement Fuel Cell $[€]$ \\
\hline
\end{tabular} & $24,000[8][24]$ \\
\hline
\end{tabular}

Several options will be considered for the assessment of the cost of hydrogen. The solutions studied are shown in the Table $\mathbf{1 8}$ and the production costs will be explained in the next section 5.3.1 and 5.3.2.

Table 18. Hydrogen costs

\begin{tabular}{|c|c|}
\hline Hydrogen production method & $\begin{array}{c}\text { Costs } \\
€ / \mathrm{kg}\end{array}$ \\
\hline SMR with CCS & 4.91 \\
\hline $\begin{array}{c}\text { Electrolysis with electricity supplied by the } \\
\text { Italian grid }\end{array}$ & 7.60 \\
\hline Electrolysis with electricity supplied by FER & 9.2 \\
\hline
\end{tabular}

In Table 19 is reported the Capex of the FC Bus fleet for the two scenarios.

Table 19. Capex of the FC Bus fleet

\begin{tabular}{|c|c|c|}
\hline Scenario & 1 & 2 \\
\hline Capex FC Bus [€] & $9,375,000$ & $18,750,000$ \\
\hline $\begin{array}{c}\text { Disposal cost estimated at } \\
1 \% \text { del Capex }\end{array}$ & \multicolumn{2}{|c|}{$1,00 \%$} \\
\hline Disposal Cost $[€]$ & 93,750 & 187,500 \\
\hline Replacement Stack Cell [€] & 360,000 & 720,000 \\
\hline
\end{tabular}

For hydrogen-powered buses, the operating costs obtained with the TCO method are shown below by varying the purchase cost of hydrogen, considering three different procurement methods.

\subsubsection{Case 1 Hydrogen from SMR with CCS (Blue Hydrogen)}

Steam Reforming (SR) or Steam Methane Reforming (SMR) is a methodology used for the production of hydrogen exploiting the reaction of hydrocarbons with water. Therefore, if hydrogen has to play a role in reducing the impact of climate change, it will need to be produced with concomitantly low carbon dioxide emissions, which, when using natural gas as a feedstock, implies coupling it with carbon capture and storage (CCS) technologies. The estimated production costs for the EU markets today, for fossil-based hydrogen, are highly dependent on natural gas prices. In 2020 hydrogen from
SMR without $\mathrm{CO}_{2}$ capture and storage has an estimated cost of $1,41 € / \mathrm{kg}$ [30]. $\mathrm{CO}_{2}$ capture and storage process generates an additional production cost estimated at around $€ 0.50 / \mathrm{kg}$ [31][32]. For the evaluation of the cost of hydrogen to the nozzle pump, must be evaluated the additional costs for storage and distribution. Another costs that have a significant impact is related to the Refueling station (HRS). These costs change in each different European countries. A study based in Germany [33] evaluates them in a range from 2 to $4 € / \mathrm{kg}$. In this paper an average cost of $3 € / \mathrm{kg}$ is estimated. The distribution costs at the pump is therefore estimated by us at 4,91 $€ / \mathrm{kg}$. In Table 20 the Opex of the FC Bus fleet for the two scenarios are reported.

Table 20. Opex of the FC Bus fleet

\begin{tabular}{|c|c|c|}
\hline Scenario & 1 & 2 \\
\hline Fuel Costs Annual $[€]$ & $€ 530,280$ & $€ 1,060,560$ \\
\hline Maintenance cost $[€]$ & $€ 594,000$ & $€ 1,188,000$ \\
\hline Total Opex FC Bus $[€]$ & $€ 1,124,280$ & $€ 2,248,560$ \\
\hline
\end{tabular}

Table 21 shows the NPV and the operating cost in $€ / \mathrm{km}$ and the\% Capex and \% Opex for the FC Bus fleet with hydrogen produced by SMR with CCS.

Table 21. NPV and operating cost of FC Bus fleet-SMR and CCS

\begin{tabular}{|c|c|c|}
\hline Scenario & 1 & 2 \\
\hline NPV [ $€]$ & $20,269,520$ & $40,539,040$ \\
\hline Operating cost $€ / \mathrm{km}$ & 1.251 & 1.251 \\
\hline \% Capex & $90 \%$ & $90 \%$ \\
\hline \% Opex & $10 \%$ & $10 \%$ \\
\hline
\end{tabular}

\subsubsection{Production of hydrogen by electrolysis}

The production of hydrogen through water electrolysis is a process that requires a lot of energy. The consumption of electricity to produce one $\mathrm{kg}$ of hydrogen is in the range of 54 to $65 \mathrm{kWh}$ [35] therefore the cost of electricity has a significant impact on its cost.

\subsubsection{Case 2 Electrolysis with electricity supplied by the Italian grid}

This scenario requires the purchase of electricity from the Italian national grid. In 2020, the costs of hydrogen production using grid electricity in the EU were estimated in the range $1.8-7.7 € / \mathrm{kg}$ [31]. In Italy the cost is estimated at $4.1 € / \mathrm{kg}$ [30]. Therefore, for the above cost considerations, the pump cost is valued at $7.6 € / \mathrm{kg}$.

In Table 22 the Opex of the FC Bus fleet for the two scenarios are reported with Hydrogen produced with electricity supplied by the Italian grid.

Table 22. Opex of the FC Bus fleet

\begin{tabular}{|c|c|c|}
\hline Scenario & 1 & 2 \\
\hline Fuel Costs Annual $[€]$ & 820,800 & $1,641,600$ \\
\hline Maintenance cost $[€]$ & 594,000 & $1,188,000$ \\
\hline
\end{tabular}


Total Opex FC Bus $[€]$

$1,414,800$

$2,829,600$

Table 23 shows the NPV and the operating cost in $€ / \mathrm{km}$ and the\% Capex and \% Opex for the FC Bus fleet with electricity supplied by the Italian grid.

Table 23. NPV and operating cost of FC Bus fleet Hydrogen from electricity supplied by the Italian grid

\begin{tabular}{|c|c|c|}
\hline Scenario & 1 & 2 \\
\hline NPV [€] & $22,996,072$ & $45,992,143$ \\
\hline Operating cost $€ / \mathrm{km}$ & 1.420 & 1.420 \\
\hline$\%$ Capex & $87 \%$ & $87 \%$ \\
\hline$\%$ Opex & $13 \%$ & $13 \%$ \\
\hline
\end{tabular}

\subsubsection{Case 3 Electrolysis with electricity supplied by FER (Green Hydrogen)}

This scenario envisages that electricity is purchased entirely from renewable sources assuming a production cost of $5.7 € / \mathrm{kg}$ [30] and a pump cost of $9.2 € / \mathrm{kg}$, due to the previous considerations on the additional cost. In Table 24 the Opex of the FC Bus fleet for the two scenarios are reported.

Table 24. Opex of the FC Bus fleet

\begin{tabular}{|c|c|c|}
\hline Scenario & 1 & 2 \\
\hline Fuel Costs Annual $[€]$ & 993,600 & $1,987,200$ \\
\hline Maintenance cost $[€]$ & 594,000 & $1,188,000$ \\
\hline Total Opex FC Bus $[€]$ & $1,587,600$ & $3,175,200$ \\
\hline
\end{tabular}

Table 25 shows the NPV and the operating cost in $€ / \mathrm{km}$ and the \% Capex and \% Opex for the FC Bus fleet

Table 25. NPV and operating cost of FC Bus fleet Hydrogen with electricity supplied by FER

\begin{tabular}{|c|c|c|}
\hline Scenario & 1 & 2 \\
\hline NPV [€] & $24,617,812$ & $49,235,625$ \\
\hline Operating cost $[€ / \mathrm{km}]$ & 1.520 & 1.520 \\
\hline$\%$ Capex & $86 \%$ & $86 \%$ \\
\hline \% Opex & $14 \%$ & $14 \%$ \\
\hline
\end{tabular}

\section{Carbon footprint}

A carbon footprint corresponds to the whole amount of greenhouse gases (GHG) produced to, directly and indirectly, support a person's lifestyle and activities. Carbon footprints are usually measured in CO2eq, [35] during the period of one year, and they can be associated with an individual, an organization, a product or an event, among others. The GHGs whose sum results in a carbon footprint can come from the production and consumption of fossil fuels, food, manufactured goods, materials, roads or transportation. It not simple to calculate carbon footprints due to poor knowledge and short data regarding the complex interactions between contributing processes including the influence of natural processes that store or release carbon dioxide. The analysis that considers the entire cycle is the so-called "from Cradle to Grave", which in the case of fossil fuels takes the name of "Well to Wheel" (WTW) [35][36] which is increasingly used as a tool decision support to provide an effective contribution towards greater asset sustainability. The Well to Wheel, analysis is often divided into two phases respectively called: Well to tank (WTT) and Tank to Wheel (TTW). The WTT and TTW for the three types of buses powered by Diesel, LNG and Hydrogen, are reported below. The Upstream fuel emissions (WTT) are based on the extraction, refining, transport and distribution of fuels.

\subsection{DF Bus}

Table 26 shows the WTT emissions related to the production of Diesel [38].

Table 26. Emissions WTT DF Bus

\begin{tabular}{|c|c|c|}
\hline \multicolumn{3}{|c|}{ Emissions WTT DF Bus } \\
\hline Scenario & 1 & 2 \\
\hline $\begin{array}{l}\text { Emissions WTT } \mathrm{CO}_{2 \mathrm{eq}}[\mathrm{g} / \mathrm{kg}] \\
\text { of fuel produced }\end{array}$ & \multicolumn{2}{|c|}{$3,150[38]$} \\
\hline $\begin{array}{c}\text { Total Emissions WTT CO } \mathrm{CO}_{2 \mathrm{eq}} \\
{[\mathrm{t} / \text { year }]}\end{array}$ & $2,083.73$ & $4,167.45$ \\
\hline
\end{tabular}

In Table 27 show the TTW emissions related to the use of Diesel Bus [39]

Table 27. Emissions TTW DF Bus

\begin{tabular}{|c|c|c|}
\hline \multicolumn{2}{|c|}{ Emissions TTW DF Bus } \\
\hline Scenario & 1 & 2 \\
\hline Emissions TTW CO $2 \mathrm{eq}[\mathrm{g} / \mathrm{km}]$ & \multicolumn{2}{|c|}{$1,129[39]$} \\
\hline $\begin{array}{c}\text { Total Emissions TTW CO } \\
\text { [t/year }\end{array}$ & $1,524.15$ & $3,048.30$ \\
\hline
\end{tabular}

In Table 28 show the WTW emissions for the DF-Bus

Table 28 Emission WTW for DF Bus

\begin{tabular}{|c|c|c|}
\hline \multicolumn{3}{|c|}{ Emissions WTW DF Bus } \\
\hline Scenario & 1 & 2 \\
\hline $\begin{array}{c}\text { Total Emissions WTW CO } 2 \text { eq } \\
{[\mathrm{t} / \text { year] }}\end{array}$ & $3,607.88$ & $7,215.75$ \\
\hline
\end{tabular}

\subsection{LNG Bus}

In Table 29 shows the WTT emissions related to the production of LNG fuel (16,52 $\left.\mathrm{g} \mathrm{CO}_{2} / \mathrm{MJ}\right)$ [40]

Table 29. Emissions WTT LNG

\begin{tabular}{|c|c|c|}
\hline \multicolumn{2}{|c|}{ Emissions WTT LNG Bus } \\
\hline Scenario & 1 & 2 \\
\hline $\begin{array}{c}\text { Emissions WTT CO } \\
\text { 2eq }[\mathrm{g} / \mathrm{kg}] \text { of } \\
\text { fuel produced }\end{array}$ & \multicolumn{2}{|c|}{$803[40]$} \\
\hline $\begin{array}{c}\text { Total Emissions WTT CO } \\
\text { [t/year }\end{array}$ & 476.98 & 953.96 \\
\hline
\end{tabular}

In Table 30 shows the TTW emissions related to the use of LNG Bus[39].

Table 30. Emissions TTW LNG Bus

\begin{tabular}{|c|c|c|}
\hline \multicolumn{3}{|c|}{ Emissions TTW LNG Bus } \\
\hline Scenario & 1 & 2 \\
\hline Emissions TTW CO2eq $[\mathrm{g} / \mathrm{km}]$ & \multicolumn{2}{|c|}{$1,096[39]$} \\
\hline $\begin{array}{c}\text { Total Emissions TTW CO } \\
{[\mathrm{t} / \text { year }}\end{array}$ & $1,479.60$ & $2,959.20$ \\
\hline
\end{tabular}

In Table 31 show the WTW emissions for the LNG-Bus 
Table 31 Emission WTW for LNG Bus

\begin{tabular}{|c|c|c|}
\hline \multicolumn{3}{|c|}{ Emissions WTW LNG Bus } \\
\hline Scenario & 1 & 2 \\
\hline $\begin{array}{c}\text { Total Emissions WTW CO } \\
\text { [t/year }\end{array}$ & $1,956.58$ & $3,913.16$ \\
\hline
\end{tabular}

\subsection{FC Bus}

In Table 32 show the WTT emissions related to the production of Hydrogen from SMR with CCS [41]

Table 32. Emissions WTT Hydrogen production from SMR with CCS

\begin{tabular}{|c|c|c|}
\hline \multicolumn{2}{|c|}{ Emissions WTT Hydrogen SMR-CCS } \\
\hline Scenario & 1 & 2 \\
\hline $\begin{array}{c}\text { Emissions WTT CO } 2 \text { eq }[\mathrm{g} / \mathrm{kg}] \\
\text { of fuel produced }\end{array}$ & \multicolumn{2}{|c|}{$3,130[41]$} \\
\hline $\begin{array}{c}\text { Total Emissions WTT } \mathrm{CO}_{2 \mathrm{eq}} \\
\text { [t/year] }\end{array}$ & 338.04 & 676.08 \\
\hline
\end{tabular}

In Table 33 shows the WTT emissions relating to the production of hydrogen at the pump in HRS, with electrolysis with electricity produced from the mix of the Italian national grid. The $\mathrm{CO} 2 \mathrm{eq}$ emissions to produce one $\mathrm{kWh}$ of energy in Italy are estimated at $307.7 \mathrm{~g} \mathrm{CO}_{2 \mathrm{eq}} /$ $\mathrm{kWh}[38]$.

Table 33. Production of hydrogen by electrolysis with electricity produced from Italian national network mix

\begin{tabular}{|c|c|c|}
\hline \multicolumn{2}{|c|}{ Emissions WTT Production of hydrogen by electrolysis } \\
\hline Scenario & 1 & 2 \\
\hline $\begin{array}{c}\mathrm{CO}_{2 \mathrm{eq}}[\mathrm{g} / \mathrm{kWh} \text { electricity } \\
\text { produced }\end{array}$ & \multicolumn{2}{|c|}{$307.7[38]$} \\
\hline $\begin{array}{c}\text { Electricity consumed in the } \\
\text { HRS to produce } 1 \mathrm{~kg} \text { of } \mathrm{H} 2 . \\
{[\mathrm{kWh}]}\end{array}$ & \multicolumn{2}{|c|}{60} \\
\hline $\begin{array}{c}\text { Emissions WTT CO} \text { eq }[\mathrm{g} / \mathrm{kg}] \\
\text { of fuel produced }\end{array}$ & 18,462 \\
\hline $\begin{array}{c}\text { Total Emissions WTT } \mathrm{CO}_{2 \mathrm{eq}} \\
\text { [t/year] }\end{array}$ & $1,993.30$ & $3,987.79$ \\
\hline
\end{tabular}

In Table 34 show the WTT emission related to production of hydrogen by electrolysis with electricity produced from FER (20 $\mathrm{g} \mathrm{CO}_{2 \text { eq }} / \mathrm{MJ} \mathrm{H}_{2}$ ) [42]

Table 34. Production of hydrogen by electrolysis with electricity produced from FER

\begin{tabular}{|c|c|c|}
\hline \multicolumn{3}{|c|}{$\begin{array}{c}\text { Emissions WTT Production of hydrogen by electrolysis with } \\
\text { electricity produced from FER }\end{array}$} \\
\hline Scenario & 1 & 2 \\
\hline $\begin{array}{c}\text { Emissions WTT CO } \\
\text { eq }[\mathrm{g} / \mathrm{kg}] \text { of } \\
\text { fuel produced }\end{array}$ & \multicolumn{2}{|c|}{2,400} \\
\hline $\begin{array}{c}\text { Total Emissions WTT CO } \mathrm{CO}_{2 \mathrm{q}} \\
\text { [t/year] }\end{array}$ & 259.20 & 518.40 \\
\hline
\end{tabular}

The TTW emissions for the FC Bus are zero as there are no emissions from the tailpipes.

\section{CONCLUSIONS}

This paper shows that the LNG solution is, nowadays, an improvement of DF Bus solution both from economic and environmental point of view. The higher purchase price of LNG buses, consisting in bigger Capex, does not affect the quality of the solution chosen over the full operating life. The lower operating costs met advantage the LNG solution to have more profitable operating costs $€ / \mathrm{km}$ than the DF Bus solution, see (Table 12 and Table 16). The FC Bus solution shows a higher operating cost $€ / \mathrm{km}$. The higher costs of this solution are linked to the higher price of acquiring buses and fuel, which, however, is needed in smaller quantities. As can be seen from tables 21, 24 and 27 , the price change of hydrogen relative to the production method used, involves a significant change in operating costs. If the purchase cost of the FC Bus sees a reduction of $5 \%$ per year for the next 10 years and the price of green hydrogen does not exceed the value of 5 $€ / \mathrm{kg}$, a scenario would arise in which operating costs $€ / \mathrm{km}$ of the hydrogen solution would approach those of DF and LNG Bus. A further reduction in the price of hydrogen, below $3 € / \mathrm{kg}$, would bring the operating costs of the hydrogen scenario below $1 € / \mathrm{km}$. About the environmental aspect, the LNG solution is an improvement over the Diesel solution for both WTT and TTW emissions. Furthermore, this solution involves lower WTT emissions even compared to the FC Bus solution with hydrogen produced by SMR with CCS. However, comparing the overall emissions data (WTT + TTW) of the three solutions (DF, LNG and FC Bus), with hydrogen produced by SMR with CCS, it emerges that the hydrogen solution has the least impact on the environment. The study highlights that WTT emissions related to the production of hydrogen from electrolysis are related to the method of producing electricity. In fact, the use of electricity produced by the Italian national grid involves more emission of $\mathrm{CO}_{2 \mathrm{eq}}$ than fossil solutions. However, the total emissions (WTT + TTW) are lower than the DF Bus solution and higher than the LNG Bus solution. The best solution, and desirable in the near future, from the environmental point of view, is represented by the production of hydrogen from water electrolysis, using the electricity produced from renewable sources. This solution have a strong environmental benefits in terms of $\mathrm{CO}_{2 \text { eq }}$ emissions. In the other cases, the advantage of using hydrogen is not very strong. Finally, the choice of having two service levels (A-B) was made to evaluate the possible scale effect on capex, but the value of the capex remained unchanged.

\section{References}

[1] https://ec.europa.eu/clima/policies/international/negoti ations/paris_en. (Accessed: April 2021).

[2] Hydrogen roadmap europe, Fuel Cells and Hydrogen 2 Joint Undertaking, 2019.

[3] D. Romano, C. Arcarese, A. Bernetti, A. Caputo, M. Cordella, R. De Lauretis, E.Di Cristofaro, A.Gagna, B. Gonella, F. Moricci, G. Pellis, E. Taurino, M. Vitullo.

[4] ISPRA, National Inventory Report, Istituto Superiore per la Protezione e la Ricerca Ambientale April 2020.

[5] Air quality in Europe 2020 report, EEA Report No 09/2020, ISSN 1977-8449

[6] https://www.ispionline.it/en/pubblicazione/leading-waytowards-successful-energy-transition-role-lng-25140. (Accessed: April 2021).

[7] https://www.governo.it/sites/governo.it/files/PNRR.pdf (Accessed: September 2021). 
[8] https://ec.europa.eu/energy/topics/energy-systemintegration/hydrogen_en\#eu-hydrogen-strategy (Accessed: September 2021)

[9] https://www.iea.org/reports/the-future-of-hydroge (Accessed September 2021)

[10] Selin Gundes, The Use of Life Cycle Techniques in the Assessment of Sustainability, Urban Planning and Architecture Design for Sustainable Development, UPADSD 14- 16 October 2015.

[11] https://ec.europa.eu/transport/sites/transport/files/the mes/strategies/doc/2011_white_paper/white-paper-illustratedbrochure_it.pdf. (Accessed: April 2021).

[12] T. Ammendola, I. Calcaterra, A. Cardoni, P. Carrozzi, R. Cipollone, C. Dionigi, M. L. Giarrizzo, E. Iegri, S. Iuliano, F. Mori, O. Noci, L. Panzali, L. Papacci, S. Pascucci, R. Polverini, G. Rauco, S. Sammarco, N.Signoretti, C. Villani, Rapporto statistico sull'area metropolitana romana, 2019.

[13] https://www.snam.it/it/trasporto/Archivio/Annotermico_2013_2014/Info-agli-utenti/.(Accessed: September 2021).

[14] https://www.enestas.com/advantages-of-lng-vsdiesel/?lang=en. (Accessed: April 2021).

[15] https://theconversation.com/hydrogen-where-is-lowcarbon-fuel-most-useful-for-decarbonisation-147696. (Accessed: April 2021).

[16] https://www.snam.it/en/energy_transition/hydrogen/sn am_and_hydrogen/.(Accessed: September 2021).

[17] https://www.trentinotrasporti.it/azienda/trentinotrasporti/autoBus-e-treni/400-emissioni-e-consumi-degliautoBus. (Accessed: April 2021).

[18] https://cdnwp.dealerk.com/eed49ed7/uploads/sites/553 /2019/04/crossway-pro-scheda-tecnica.pdf. (Accessed: April 2021).

[19] https://www.regione.emilia-

romagna.it/notizie/2021/marzo/mobilita-flessibile-integratosicuro-e-digitale-presentate-le-linee-guida-del-trasportopubblico-investimento-per-oltre-240-milioni-di-euro. (Accessed: April 2021).

[20] https://www.irizar.com/brasil/en/irizar-incorporatesnatural-gas. (Accessed: April 2021).

[21] https://www.sustainable-Bus.com/news/irizar-is-readyto-launch-cng-and-lng-intercity-Buses-and-coaches/ (Accessed: April 2021).

[22] https://www.solarisbus.com/en/vehicles/zeroemissions/hydrogen "Zero Emissions Powertrains Product Catalogue 2021/2022”. (Accessed: April 2021).

[23] Ballard Jen 2021 Fuel Cell Electric Buses Proven Performance and the Way Forward.

[24] Roland Berger, Fuel Cell Electric Buses -Potential for Sustainable Public Transport in Europe, A Study for the Fuel Cells and Hydrogen Joint Undertaking, FCH JU -

Commercialization Strategy for Fuel Cell Electric Buses in Europe, 2015.

[25] Dipartimento Mobilità e Trasporti Direzione Trasporto Pubblico Locale UFFICIO GESTIONE CONTRATTI SOCIETÃ PRIVATE Determinazione Dirigenziale NUMERO REPERTORIO QG/814/2020 del 19/08/2020 NUMERO PROTOCOLLO QG/26435/2020 del 19/08/2020 “Comune di Roma”.

[26] https://dgsaie.mise.gov.it/prezzi-annualicarburanti?pid=2. (Accessed: April 2021).

[27] Roland Berger GmbH, "Fuel Cell Electric Buses - Potential For Sustainable Public Transport In Europe.” München: The
Fuel Cells and Hydrogen Joint Undertaking, 2015. Web. November 1, 2016.

[28] https://www.tper.it/Trasporto Passeggeri EmiliaRomagna - S.p.A Sede legale Via di Saliceto, 3 - 40128 Bologna. Accessed: April 2021. (Accessed: April 2021).

[29] Ivan Smajla, Daria Karasalihović Sedlar, Branko Drljača and Lucija Jukić, Fuel Switch to LNG in Heavy Truck Traffic,6 February 2019, Energies 2019, 12, 515; doi:10.3390/en12030515

[30] https://www.sustainable-Bus.com/news/major-fuel-cellBus-order-for-solaris-from-rvk-cologne-15-solaris-hydrogen-ondelivery/.(Accessed: April 2021).

[31] Hydrogen Europe Clean Hydrogen Monitor 2021, Hydrogen Europe

[32] Global Hydrogen Review 2021, International Energy Agency Website: www.iea.org

[33] IEAGHG Technical Report 2017-02, Techno-Economic Evaluation of SMR Based Standalone (Merchant) Hydrogen Plant with CCS.

[34] Markus Reußa, Thomas Grubea, Martin Robiniusa, Detlef Stoltena, "A hydrogen supply chain with spatial resolution: Comparative analysis of infrastructure technologies in Germany"

[35] John A. Turner, Sustainable Hydrogen Production Science, 305 (5686), DOI: 10.1126/science.1103197

[36] Well-To-Wheels Analysis of Future Automotive Fuels And Powertrains In The European Context. European Commission Joint Research Centre Institute for Energy and Transport. Report EUR 26237 EN 2014.

[37] V. Konecný, J. T. Settey, F. Petro, T. Skrúcaný and T. Figlus. Environmental Sustainability of the Vehicle Fleet Change in Public City Transport of Selected City in Central Europe, Energies 2020, 13, 3869; doi:10.3390/en13153869

[38] Caserini, P. Baglione, D. Cottafava, M. Gallo, F. Laio, G. Magatti , V. Maggi, M. Maugeri, L. Moreschi , E. Perotto , L. Pizzol, E. Semenzin, A. Senese; FATTORI DI EMISSIONE DI CO2 PER CONSUMI ENERGETICI E TRASPORTI PER GLI INVENTARI DI GAS SERRA DEGLI ATENEI ITALIANI dx.doi.org/10.32024/ida.v6i1.207 Ingegneria dell'Ambiente Vol. 6 n. 1/2019 Stefano.

[39] Alternative Bus Technologies August, 2018 Produced by: C40 Cities Finance Facility in collaboration with Grütter Consulting.

https://cffrod.s3.amazonaws.com/storage/files/J5uOxG6boRSm 6lb8EyU81ACO1Y3EhX53gx1yEKJs.pdf

[40] D. A. Hagos, E. O. Ahlgren. Well-to-wheel assessment of natural gas vehicles and their fuel supply infrastructures Perspectives on gas in transport in Denmark. https://doi.org/10.1016/j.trd.2018.07.018.

[41] C. Antonini, K. Treyer, A. Streb, M. van der Spek, C. Bauer and M. Mazzotti Hydrogen production from natural gas andbiomethane with carbon capture and storage - A technoenvironmental analysis. DOI: 10.1039/d0se00222d

[42] Fuel Cells and Hydrogen Applications for Regions and Cities Vol. 2 Brussels and Frankfurt, September 2017 Roland Berger and $\mathrm{FCH}$ 